Gharehbiglo Hossein, Assistant Professor, Department of Management, Ajab Shir Branch, Islamic Azad University (Ajabshir, Iran);

Mofid Seyed Alireza,

MSc of Executive Management, Department of Management, Bonab Branch, Islamic Azad University (Bonab, Iran);

Charandabi Siroosnezhad Ehsan, PhD Student in Marketing Management, Department of Management, Ajab Shir Branch, Islamic Azad University (Ajabshir, Iran),

CEO at Mobiya Market Research Company, Mobiya Group (Tabriz, Iran);

Piroozinia Hassan,

MSc of Executive Management, Department of Management, Bonab Branch, Islamic Azad University (Bonab, Iran)

\title{
EXAMINING THE FACTORS EFFECTIVE ON BRAND EQUITY FROM POTENTIAL AND ACTUAL CUSTOMER'S VIEWPOINT
}

Brand is one of the most valuable assets of a business and paying attention to the concepts such as brand, brand management, and brand equity improves mental image of the consumers regarding the business and the sale in return. The general purpose of the present study is to survey and elaborate on the factors effective on brand equity from the potential and actual customer's viewpoint. To this end, Aaker's theory was adopted as theoretical framework with 4 hypotheses. By emphasizing on the model and the consumer behavior-based approach and taking into account the actual/potential consumers of organization, the study is aimed at doing a survey to find the relationship between the different aspects of brand equity in Aaker's model (brand loyalty, brand awareness, brand quality, and brand association) and brand equity from the customer's viewpoint (knowledge equity, attitude equity, and relationship equity). Sampling was performed through cluster random sampling and the data gathering tool was Yoo and Denthu's standard brand equity questionnaire. The findings showed that brand loyalty, brand awareness, and brand quality are effective on brand equity from the actual customer's viewpoint. The findings make a great contribution to the process of finding better strategies to improve brand equity. To use the results at practical level, the indices of the variables effective on brand equity can be organized as statements of a questionnaire to measure realization of one or more indices of brand equity. The questionnaire should be filled out by the managers to measure a firm's readiness to improve brand equity.

Keywords: brand equity, brand loyalty, brand awareness, perceived brand quality, brand association

DOI: 10.21272/mmi.2017.1-07

Introduction. Personality of brand constitutes the centerpiece and the main variable in the customer's choice among different alternatives. Workforce, land, and capital are the three main elements of production and the source of wealth in the classical economy model. However, the model cannot explain how a product can be sold for higher price comparing with another product with identical quality, appearance, and function. The modern approaches to marketing explain this based on brand value from the customer's viewpoint $[13$, p. 50]. A popular brand is preferences for the customer in choosing among similar products. In many markets, brand creates a specific identity for a product and connects it to a specific group in the society. From psychological viewpoint, in addition to superficial function, branded products bring prestige and self-confidence to the customer, and therefore, the customer is willing to pay higher prices for the product. In addition, the brand conveys higher quality of the product and by purchasing brand product, the customer believes that they have acquired something valuable. The point 
is, like capital, technology, and raw materials, brand is effective on creating value added for an organization. The customer and the organization both enjoy advantages of brand. Once the customer uses a branded product to find out that it is superior to similar products, they grow interest in using that brand in the future. Brands convey information of higher quality, performance, and other aspects of the products so that the customer experiences lower risks by choosing them. Brand gives meaning to the customer and constitutes part of their wealth. Brand identity, in todays' marketing world, is an interesting concept. Brand equity can be improved through effective customer management, showing respect to the customer, and paying attention to their needs. There is a positive relationship between performance and credit of a brand so that a firm can enjoy higher share of market and business value in return by increasing its creditability. It is notable that part of creditability of a business depends on its past regarding financial and social aspects. Being considered as firm that respects moral values adds to the creditability of the firm, which in return improves position of the firm in the market [8, p. 325].

In the modern highly competitive world, those companies will be successful which distinguish themselves from competitors and create ideal and unique position in their consumers' mind [11, p. 126]. One of the ways to create permanent competitive advantage in these markets being paid little attention previously, is the creation of brand equity, namely the value which is added to products and services because of having brand, and it can be created, maintained and supported.

Companies inform consumers about brand through marketing activities and create an ideal image of brand in their mind by creating association and take steps to promote brand equity [15, p. 843]. Brand equity has many advantages for companies and producers, for example if a brand has high net worth, the target consumer will have positive behavior to brand, thus he/she tends to pay high price for product, to continue his/her purchase and to advertise the product among people [10, p. 427].

In addition to measurement of brand equity, understanding the way of creating brand equity and how it affects consumer's view and behavior is a matter of great importance, since finally success rate of a brand worth in market will be evaluated through actions and reactions of its consumers. In the modern trade world, understanding the behavior of consumer and recognizing the important characteristics of product which play a role in his/her decision-making, are considered as backbone for marketing plans of every organization. There have been few and discontinuous researches to study the factors affecting brand equity $[3$, p. 66]. especially the brand equity has not been evaluated from actual and potential customers, point of view. Therefore, considering the lack of experimental researches in this field, the importance of recognizing the factor affecting brand net worth from actual and potential customers, point of view becomes evident in attracting and preserving customers and creating difference in competitive environment and market. Thus, the aim of this research is to study the factors affecting brand net worth from organization actual and potential customer' point of view.

Problem statement. Equity of brand, name, sign, logo, design, or a mixture of these elements determines identity of a service organization and makes it distinguishable from its rivals. It addition, through its brand, the organization is judged by reason, feelings, and logic of the customer. Creating a sense of assurance of quality and reliability is one of the programmed roles of brand as the brand signals life style, personality, ideals, and behaviors of the customer [7, p. 99]. Along with expansion of and development of information technology, all measures and decisions made by the organization is evaluated based on its brand; so, that the brand highlights successes or failures of the organization or brand. Brand or commercial logo is considered as an asset for many businesses and value of a brand might be evaluated much more than the value of tangible assets. On the other hand, brand is mental and psychological matter that should reside in the mind of the consumer, the customer, shareholders, employees, and users. Brands are featured with social nature and a brand is successful when the members of society feel attachment to the brand as their own property so that they would make any efforts to improve position of the brand in the society. Consequently, the customer promotes the brand 
as unpaid marketing agent for the brand. The brand consumer promotes and introduces the brand in the society without seeking financial interests [12, p. 65].

In marketing, the brands are often the starting point of distinction between products and the offered services, and products and currently competitive services in market so that this matter can play an important role in the success of organizations. In recent years, brand and specially brand net worth have attracted the attention of marketing research and academics and so far, this matter has been studied extensively. Identifying the constructs constituting brand net worth and studying different marketing activities resulting in reinforcement of these constructs on one hand and presenting models for measuring brand net worth on the other have become undeniable matter for various companies and industries. Although current researches have concentrated on creation and conceptualization of brand net worth, there has been no consensus about its measurement method and which constructs should include the process of brand net worth measurement [2, p. 241]. Each one of approaches based on customer has studied the constructs of brand net worth from different dimensions and has presented a model for them [1, p. 325]. Therefore, accurate and exact recognition of brand net worth concepts and practicing its constructs is necessary so that to allow researcher to measure them empirically and to analyze the factors relevant to brand net worth in market effectively. On the other hand, by appearance and opening of chain stores along with stores modern structures and offering appropriate and high quality services, increasing competition for earning significant share from market has been created and as a result appropriate marketing and sales units have been formed in these companies and they have begun advertisement and promotional activities. The main part of these activities is to depict and to recognize brand net worth and its constructs mostly and exactly, to explain consolidated samples and models, to design and to plan relevant activities to promote sales and innovation in service offering quality. Therefore, considering that one of the practical ways to increase brand net worth which results in loyalty of customers is to pay attention to customers awareness along with mental imagination and views and perceived quality of brand which affect the way of interpreting and explaining the kind of consumers behavior, thus it can be an effective strategy for attaining competitive advantage so that identifying the factors affecting brand net worth promotion is very important for ETKA chain stores from actual and potential customers point of view about attracting and preserving customers and creating competitive advantage, Based on the above, following questions are stated:

1. Is there a direct relationship between brand loyalty and brand/logo equity?

2. Is there a direct relationship between brand awareness and brand/logo equity?

3. Is there a direct relationship between brand perceived quality and brand/logo equity?

4. Is there a direct relationship between brand associations and brand/logo equity?

Necessity of the study. A brand with functional concept is defined as a brand designed to meet consumption needs, which are created externally. Symbolic needs are defined as interest in the products that meet the internal needs for improving personality, situation, role, position in a group, and introducing oneself. Based on Akare's (1991) model, the main aspects of brand equity are brand quality, brand loyalty, brand awareness, brand association, and other assets associated with brand (e.g. copyright, patent, etc.). Therefore, the present study is aimed at improving brand equity by examining the different aspects of the brand and its relationship with brand equity from the customer's viewpoint.

Objectives. The main purpose of the present study is to survey and elaborate on the factors effective on brand equity from the potential and actual customer's viewpoint. To this end, following secondary objectives are introduced:

1. Determining the extent of brand loyalty and its effect on brand equity from the actual and potential customer's viewpoint.

2. Determining the extent of brand awareness and its effect on brand equity from the actual and potential customer's viewpoint. 

цінність бренда з точки зору потенційних і фактичних споживачів

3. Determining the extent of brand quality and its effect on brand equity from the actual and potential customer's viewpoint.

4. Determining the extent of brand association and its effect on brand equity from the actual and potential customer's viewpoint.

Applied objectives. To propose recommendations and guidelines to improve brand equity from the actual and potential customers' viewpoint based on the identified factors.

Theoretical framework. Several studies have focused on brand equity and several methods have been proposed to evaluate it. Erdom and Soawt (2004) classified the methods for measuring brand equity into elements-based and holistic models. The former models deals with single elements of brand equity and the later models try to give a general assessment of the brand. Aaker defined brand equity as a set of five items if assets (debts) of brand that are attached to a name or symbol of brand and increase (decrease) the value of a product. These five items are brand loyalty, brand awareness, perceived quality of brand, brand associations, and brand proprietary rights (Fig. 1).

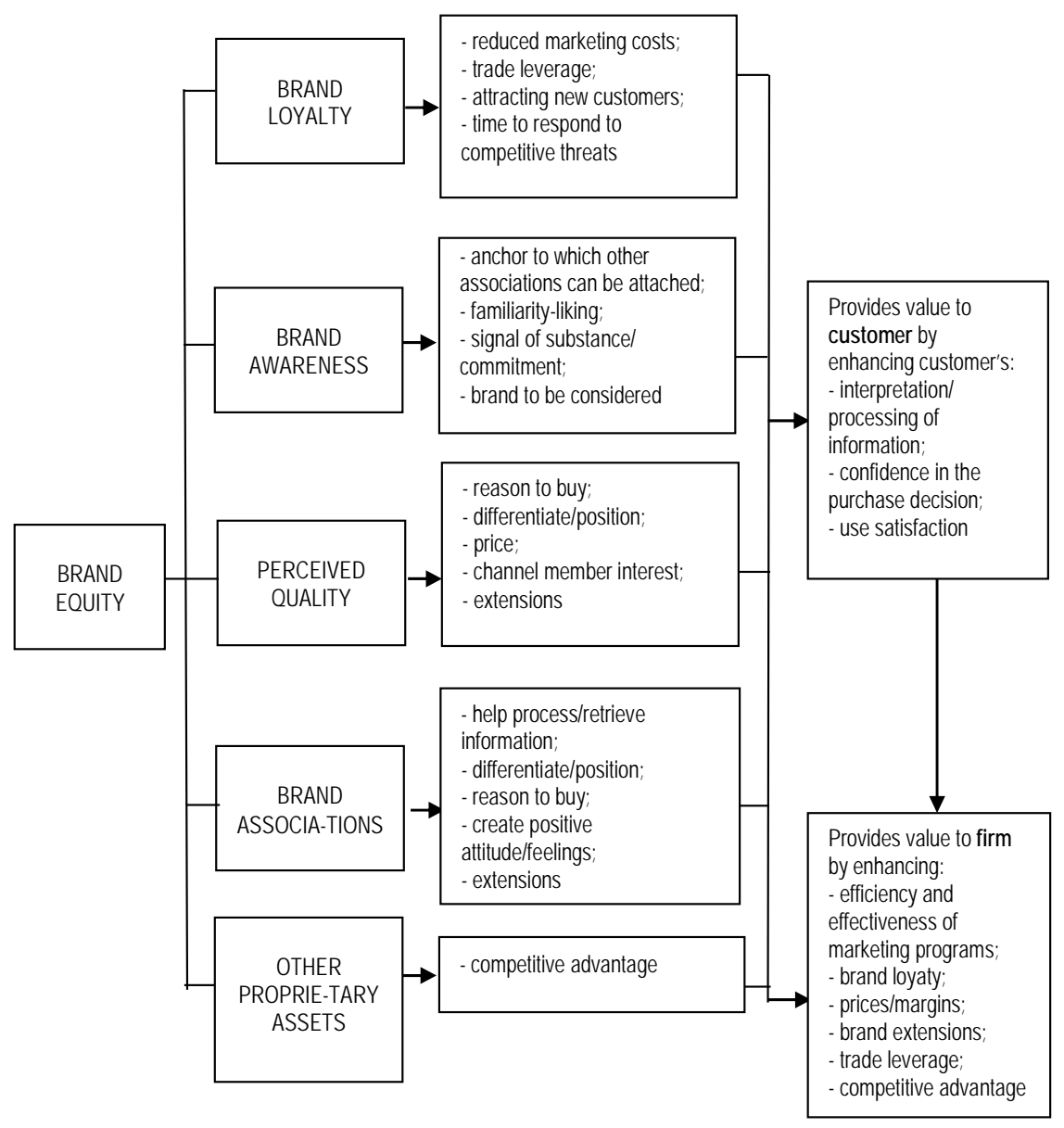

Figure 1 - Aaker's model (1991) 
Aaker's definition of brand equity has been used by many experimental works. Another widely used definition is Keller's definition of brand equity as distinguishing effect of brand knowledge on the consumer's response to brand marketing. According to Keller, distinguishing effect is determined by comparing the consumer's response to marketing without brand and name. On the other hand, the proposed models of brand equity based on the customer's viewpoint is based on three dimensions of knowledge brand equity, attitude brand equity, and relationship equity.

This relative classification has been supported by several studies. Keller and Leman argued that brand knowledge is comprised of awareness and communications, demands, and the attachments. While awareness is a critical elements of brand knowledge in the model, demands and the attachments represent attitude and relationship equity. Other authors have defined customer-based effects from inferential viewpoint (brand equity), effectiveness (attitude equity), and experience (relationship equity) $[17$, p. 113].

Based on the theoretical foundations of Aaker's (1991) model, the effective factors on brand equity are perceived brand quality, brand loyalty, brand awareness, brand association, and other aspects of brand (e.g. copyright and patent). In addition, the aspects of brand equity from the customer's viewpoint are knowledge equity, attitude equity, and relationship equity.

\section{Hypotheses:}

1. Brand loyalty is effective on brand equity from the potential and actual customer's viewpoint.

2. Brand awareness is effective on brand equity from the potential and actual customer's viewpoint.

3. Brand quality is effective on brand equity from the potential and actual customer's viewpoint.

4. Brand association is effective on brand equity from the potential and actual customer's viewpoint.

Literature review. Based on purpose, brand equity is defined in different ways. However, there is no consensus about the definition [16, p. 34; 9, p. 238]. The concept can be approached from supplier, retailer, and the customer's viewpoint. While the supplier and the retailer are interested in the strategic functions of brand equity, the investors are more interested in the financial aspects [4, p. 32]. The proponents of financial viewpoint define brand equity as the total value of the brand and the logo when it is sold or added to balance sheet as an independent asset [6, p. 17]. Other definitions based on this approach define brand as the cash flows that follow ascending trend for the branded goods in comparison with goods with no brand $[14$, p. 36].

The definitions of brand equity based on the customer's viewpoint try to approach the concept from the customer's viewpoint whether it is an organization or a person. According to these definitions, a brand is valuable when it is considered valuable by the customer. Therefore, power of a brand lies in the customer's attitude and experience with brand [9, p. 75]. Although, several studies have been conducted on brand equity, few authors have dealt with the effect of brand on the customer's loyalty. Jenifer Aker (1997) surveyed the way of classifying personality features such as name and logos and examined the customer's traits regarding the level of loyalty to a service or product. Moreover, Bachman (1988) studied perceived quality and brand awareness; Robert Giel (2007) studied the concept of name and logo; Shanker et al. (2003) and Rangasvami (2003) studied the customer's satisfaction with brand; Perichar et al. (1998), Blomer et al. (1999), Betti and Kal (1998), Havitz and Howard (1999) examined the customer's commitment to a brand; Morgan and Hunt (1994) lenio and Binks (1996) studied brand trust as representative of brand loyalty and Hapson (2002) studied customer-oriented culture [5, p. 122].

Methodology. Regarding the purpose, the study is an applied work and a descriptive-correlative work as to the method. Study population was comprised of the actual and potential customers of Etka Company. Sample group size was determined based on Morgan's table for unlimited population $(n=384)$. To be on the safe side, 400 questionnaires were distributed and 390 questionnaires were 
Х. Гхарехбігло, А. Сеуед Мофід, Е. Сірооснезхад Цхарандабі, Х. Піроозініа. Визначення факторів впливу на цінність бренда 3 точки зору потенційних і фактичних споживачів

retuned. Simple random sampling method was used for sampling in Tehran city. Of 390 distributed questionnaires, 290 subjects were actual (current) customers and 100 subjects were potential customers of ETKA organization.

Data gathering tool. Yoo and Deneto's sstandard questionnaire of brand equity was used for data gathering. Reliability and validity of the questionnaire have been confirmed by Washburn and Plank (2002). The questionnaire is featured with two sets of questions; one set to record demographic information and if the participant is a customer of Etka Co. or not; and one set to collect the data needed to test the hypotheses. The questions are designed based on Likert's five-point scale (Tables 1 and 2).

Table 1 - Elements of each aspect of the independent variable

\begin{tabular}{|c|c|c|}
\hline Variable & Aspect & Elements \\
\hline \multirow{15}{*}{ Independent } & \multirow{5}{*}{ Brand loyalty } & Decrease of marketing costs \\
\hline & & Improvement of business condition \\
\hline & & Awareness increase \\
\hline & & Responding to competitive pressures \\
\hline & & Creating assurance \\
\hline & \multirow{3}{*}{ Brand awareness } & Facilitating identification of brand \\
\hline & & Increasing brand equity \\
\hline & & Increasing brand loyalty \\
\hline & \multirow{4}{*}{ Perceived brand quality } & Increase of purchase motivations \\
\hline & & Creating specific position for the product \\
\hline & & Increase the customer's interest in the product \\
\hline & & Making the product distinguish \\
\hline & \multirow{3}{*}{ Brand association } & Creasing reason for making a purchase \\
\hline & & Brand development \\
\hline & & Creating positive attitudes and motivation \\
\hline
\end{tabular}

Table 2 - Elements of each aspect of the dependent variable

\begin{tabular}{|l|c|c|}
\hline Variable & Aspect & Elements \\
\hline \multirow{4}{*}{ Dependent } & \multirow{3}{*}{ Knowledge equity } & Profitability \\
\cline { 3 - 3 } & & Financial capability to purchase a brand \\
\cline { 2 - 3 } & \multirow{2}{*}{ Attitude equity } & Social image \\
\cline { 2 - 3 } & & Changing the consumer's attitude \\
\cline { 2 - 3 } & \multirow{2}{*}{ Relationship equity } & The consumer's satisfaction \\
\cline { 3 - 3 } & & Brand attitude loyalty \\
\hline
\end{tabular}

To check validity of the data gathering tool, content validity was used. So that the primary questionnaire was provided to the experts and university professors of executive management, business management, and marketing management for examination. The questionnaire was modified based on the feedbacks.

Content validity of the questionnaire was obtained 80,565 . To test reliability of the questionnaire, Cronbach's alpha was employed through pretest and analyzing the results in SPSS so that reliability of the questionnaire was obtained 0,793 . Therefore, high consistency of the questions and acceptable reliability of the questionnaire was ensured. 
Findings. The collected data was used to test the hypotheses using inferential tests (Kolmogrov Smirnov (KS) test, Pearson, and regression).

As listed in Tables 3 and 4 , the eight variables of the study are at sig. level above 0,05 . This means that research data distribution is normal, therefore Pearson test was used.

Table 3 - KS test for actual customers

\begin{tabular}{|c|c|c|c|}
\hline Variables & KS & p-value & N \\
\hline Brand loyalty & 1,213 & 0,105 & 290 \\
\hline Brand awareness & 1,350 & 0,052 & 290 \\
\hline Perceived quality & 1,189 & 0,118 & 290 \\
\hline Brand associations & 1,342 & 0,055 & 290 \\
\hline
\end{tabular}

Table 4 - KS test for potential customers

\begin{tabular}{|c|c|c|c|}
\hline Variables & KS & p-value & N \\
\hline Brand loyalty & 1,043 & 0,227 & 100 \\
\hline Brand awareness & 1,157 & 0,138 & 100 \\
\hline Perceived quality & 1,170 & 0,130 & 100 \\
\hline Brand association & 1,181 & 0,123 & 100 \\
\hline
\end{tabular}

As listed in Table 5, sig. of the variables of the actual customer is acceptable $(<0.05)$; thus, the correlation is significant. In addition, sig. level of the variables of the potential customers are unacceptable $(>0,005)$; thus the correlation is not significant. Since, we try to survey the effect of independent variables on the dependent variables, regression analysis was utilized. To this end, indices such as square correlation (R2) were used to measure correlation of the dependent and independent variables. In addition, all angular coefficients of the independent variables were calculated. Higher $\mathrm{R}$ values indicate stronger linear relationship between the dependent and independent variables. Since all the independent variables are added simultaneously to the model, "Enter Method" was used to determine the effect of all important and unimportant variables.

\section{Table 5 - Correlation coefficient of Pearson test for the dependent and independent variables}

\begin{tabular}{|c|c|c|c|}
\hline Independent variable & $\begin{array}{c}\text { Pearson } \\
\text { coefficient }\end{array}$ & Sig. & N \\
\hline Brand loyalty (actual) & 0,400 & 0,000 & 290 \\
\hline Brand awareness (actual) & 0,264 & 0,004 & 290 \\
\hline Perceived quality (actual) & 0,267 & 0,001 & 290 \\
\hline Brand association (actual) & 0,085 & 0,046 & 290 \\
\hline Brand loyalty (potential) & 0,111 & 0,272 & 100 \\
\hline Brand awareness (potential) & 0,084 & 0,404 & 100 \\
\hline Perceived quality (potential) & 0,061 & 0,548 & 100 \\
\hline Brand association (potential) & $-0,134$ & 0,183 & 100 \\
\hline
\end{tabular}

As listed in Table 6, Spearman test results are less than sig. level $(<0,05)$ for the hypotheses brand 
Х. Гхарехбігло, А. Сеуед Мофід, Е. Сірооснезхад Цхарандабі, Х. Піроозініа. Визначення факторів впливу на цінність бренда 3 точки зору потенційних і фактичних споживачів

loyalty (actual) brand awareness (actual), perceived quality of brand (actual), and brand association (actual). Therefore, there is a significant relationship between the variables and brand equity. In addition, Pearson test results are higher that sig. level $(>0,05)$ for the hypotheses brand loyalty (potential) brand awareness (potential), perceived quality of brand (potential), and brand association (potential). Therefore, there is no significant relationship between the variables and brand equity. To test the effect of each independent variable on the dependent variable of the hypotheses, regression test was used.

Table 6 - Variance analysis of the hypotheses of regression model and coefficients of parameters of the hypothesis

\begin{tabular}{|c|c|c|c|c|c|c|c|c|c|}
\hline Independent variable & $\mathrm{R}$ & R2 & $\begin{array}{c}\text { Adjusted } \\
\text { R2 }\end{array}$ & SD & t-value & $\beta$ & $\mathrm{F}$ & Sig. & Result \\
\hline Brand loyalty (actual) & 0,400 & 0,093 & 0,090 & 4,107 & 5,438 & 0,400 & 29,567 & 0,000 & $\begin{array}{c}\text { HO not } \\
\text { supported }\end{array}$ \\
\hline $\begin{array}{c}\text { Brand awareness } \\
\text { (actual) }\end{array}$ & 0,264 & 0,024 & 0,020 & 4,262 & 2,638 & 0,264 & 6,957 & 0,009 & $\begin{array}{c}\mathrm{HO} \text { not } \\
\text { supported }\end{array}$ \\
\hline $\begin{array}{c}\text { Perceived quality } \\
\text { (actual) }\end{array}$ & 0,267 & 0,036 & 0,032 & 4,236 & 3,261 & 0,267 & 10,636 & 0,001 & $\begin{array}{c}\text { HO not } \\
\text { supported }\end{array}$ \\
\hline $\begin{array}{l}\text { Brand association } \\
\text { (actual) }\end{array}$ & 0,085 & 0,011 & 0,008 & 4,289 & - & - & 3,259 & 0,072 & $\begin{array}{l}\text { H1 not } \\
\text { supported }\end{array}$ \\
\hline Brand loyalty (potential) & \multicolumn{8}{|c|}{ Correlation in Pearson test was not supported } & $\begin{array}{c}\text { H1 not } \\
\text { supported }\end{array}$ \\
\hline $\begin{array}{c}\text { Brand awareness } \\
\text { (potential) }\end{array}$ & \multicolumn{8}{|c|}{ Correlation in Pearson test was not supported } & $\begin{array}{c}\text { H1 not } \\
\text { supported }\end{array}$ \\
\hline $\begin{array}{c}\text { Perceived quality } \\
\text { (potential) }\end{array}$ & \multicolumn{8}{|c|}{ Correlation in Pearson test was not supported } & $\begin{array}{c}\text { H1- not } \\
\text { supported }\end{array}$ \\
\hline $\begin{array}{c}\text { Brand association } \\
\text { (potential) }\end{array}$ & \multicolumn{8}{|c|}{ Correlation in Pearson test was not supported } & $\begin{array}{c}\text { H1 not } \\
\text { supported }\end{array}$ \\
\hline
\end{tabular}

Clearly, $\beta$-values of the variables regarding brand equity indicate the variance of brand value based on variance of the factors effective on brand equity. One unit of positive change in brand loyalty (actual), brand awareness (actual), perceived value of brand (actual) and brand association (actual) results in $0,400,0,264,0,267$, and 0,0 unit changes in brand value respectively from the customers' viewpoint.

Table 7 - Hypotheses tests

\begin{tabular}{|c|c|}
\hline Result & Hypotheses \\
\hline Supported & Brand loyalty is effective on brand equity from the actual customer's viewpoint \\
\hline Supported & Brand awareness is effective on brand equity from the actual customer's viewpoint \\
\hline Supported & Brand quality is effective on brand equity from the actual customer's viewpoint \\
\hline Not- Supported & Brand association is effective on brand equity from the actual customer's viewpoint \\
\hline Not- Supported & Brand loyalty is effective on brand equity from the potential customer's viewpoint \\
\hline Not- Supported & Brand awareness is effective on brand equity from the potential customer's viewpoint \\
\hline Not- Supported & Brand quality is effective on brand equity from the potential customer's viewpoint \\
\hline Not- Supported & Brand association is effective on brand equity from the potential customer's viewpoint \\
\hline
\end{tabular}

Conclusions and recommendations. The main objective of this paper was to study the factors affecting brand equity from organization actual and potential customers. For this purpose, 
a questionnaire based on yoo and Donthu views in the statistical population of actual and potential customers of ETKA chain stores was distributed as random method in Tehran City. The results show that there is significant difference between actual customers point of view, loyalty to trade brand, perceived quality about trade brand and awareness about trade brand have the most effect and role in explaining brand equity, respectively, however none of the above-mentioned factors play a role in explaining brand equity from the potential customers point of view and in their views other view other factors are effective in creating brand equity construct. According to research findings and from the actual customers point of view, creating brand equity resulted in assuring customers, and appropriate response to competition threats led to increase of trade power of company. Discriminating the product and creating a position for products resulted in increment of customers' interest and purchase motivation for them. The findings of present research about actual customers are in complete agreement with findings of Aaker (1991), but from potential customer's point of view and ineffectiveness of brand association in creating brand equity, the research findings are not in agreement with findings of Aaker. This disagreement in actual and potential customers' view, can be the result of lack of brand position of aforesaid company in potential customers' view and the decision of potential customers not to purchase from store.

The present research has the limitations such as using regression method, limited statistical population for actual and potential customers of ETKA chain store in Tehran city, paying attention to brand loyalty variables, brand association, brand quality and brand awareness of creating brand equity. Thus, for further researches in order overcome the above mentioned limitations, using non-linear and neoteric advanced methods in estimating the factors affecting brand net worth construct, using a larger statistical population and considering the effect of other variables such as perceived worth, popularity and so on, in creating brand net worth construct are recommended.

Given the results regarding the effects of brand loyalty, brand awareness, and perceived quality of brand on brand equity, these three factors are worthy of more attention.

Brand loyalty. The results indicated that brand loyalty was effective on brand equity from the actual customer's viewpoint. Therefore, to improve the positive effect of this factor, following measures are recommended:

1. Issuing electronic card for the loyal customers (golden card) and offering special services such as home delivery.

2. Offering gifts in special occasions such as New Year holidays to special customers.

3. Granting special discounts and facilities for the loyal and special customers.

4. Keeping contact with the customers by noticing special offers or availability of new products or services.

5. Offering special facilities for the customers that introduce new customers to the organization.

Brand awareness. The results showed effectiveness of brand awareness on brand equity from the actual customer's viewpoint. Following measures are recommended to improve the positive effect of this factor:

1. To make sure that the customers are informed about all services of the organization.

2. To increase advertisement budget.

3. To introduce branches of the organization in interesting ways.

Perceived value of brand. The results showed that perceived value of brand was effective on brand equity from the actual customer's viewpoint. Therefore to improve the positive effect of this factor, the organization needs to:

1. Communicate competitive and positive specifications of the organization through mass media 
and word of mouth.

2. Clarify advantages of the brand over the rival and ask the customer to judge the merits of the brand. Consequently, the customer will be ensured that the brand is the best option.

3. Remove or improve the weaknesses of the brand: the weaknesses, if any, are vital to remove and solve as soon as possible.

1. Aaker, D.A. (1991). Managing Brand Equity. New York, NY: The Free Press [in English].

2. Atilgan, E., Aksoy, S., \& Akinci, S. (2007). Determinants of the brand equity. Marketing Intelligence and Planning, 23 (3), 237-248 [in English].

3. Buil, I., \& Martínez, E. (2013). The influence of brand equity on consumer responses. Journal of Consumer Marketing, 30(1), $62-74$ [in English].

4. Cobb-Walgren, C.J., \& Ruble, C.A. (1995). Brand equity, brand preference, and purchase intent. Journal of Advertising, 24(3), $25-41$ [in English].

5. Louis, D., \& Lombart, C. (2010). Impact of brand personality on three major relational consequences (trust, attachment, and commitment to the brand). Journal of Product \& Brand Management, 19(2), 114-130 [in English].

6. Feldwick, P. (1996). Do we really need brand equity? The Journal of Brand Management, 4(1), 9-28 [in English].

7. Herremans, I.M., Ryans, J.K., \& Aggarwal, R. (2000). Linking Advertising and Brand Value. Business Horizons, 43(3), 19-26 [in English].

8. Janiszewski, C., \& Van Osselaer, S.M.J. (2000). A connectionist model of brand-quality associations. Journal of Marketing Research, 37(3), 331-351 [in English].

9. Keller, K.L. (2003). Strategic Brand Management: Building. Measuring and Managing Brand Equity. 2nd Edition. Englewood Cliffs, NJ: Prentice-Hall [in English].

10. Kim, J., \& Hyum, Y. (2011). A model to investigate the influence of marketing-mix efforts and corporate image on brand equity in the IT software sector. Industrial Marketing Management, 40, 424-438 [in English].

11. Kotler, P., \& Pfoertsch, W. (2006). B2B brand management. Berlin Heidelberg: Springer [in English].

12. Lovelock, C.H., \& Wirtz, J. (2007). Services Marketing: People, Technology, strategy. 6th edition. Upper Saddle River, $\mathrm{NJ}$ : Pearson-Prentice Hall [in English].

13. Siguaw, J., Mattila, A., \& Austin, J.R. (1999). The brand-personality scale. Cornell Hotel and Restaurant Administration Quarterly, 40(3), $48-56$ [in English].

14. Simon, C.J., \& Sullivan, M.W. (1993). The measurement and determinants of brand equity: a financial approach. Marketing Science, 12(1), 28-53 [in English].

15. Van Riel, A.C.R., Pahud de Mortanges, C., \& Streukens, S. (2005). Marketing antecedents of industrial brand equity: An empirical investigation in specialty chemical Industrial. Marketing Management, 34(8), 841-847 [in English].

16. Vazquez, R., Del Rio, A.B., \& Iglesias, V. (2002). Consumer based brand equity: development and validation of a measurement instrument. Journal of Marketing Management, 18(1/2), 27-49 [in English].

17. Zeithaml, V., Trust, R., \& Lemon, K. (2001). The customer pyramid: creating and serving profitable customers. California Management Review, 43(4),106-118 [in English].

X. Гхарехбіело, асистент, кафедра управління, відділення в м. Аджаб Шир, Ісламський університет Азад (м. Аджаб Шир, Іран);

A. Сеуед Мофid, MSc, кафедра управління, відділення в м. Бонаб, Ісламський університет Азад (м. Бонаб, Іран);

E. Сірооснезхад Цхарандабі, аспірант, кафедра управління, відділення в м. Аджаб Шир, Ісламський університет Азад (м. Аджаб Шир, Іран), генеральний директор компанії "Mobiya Market Research", Mobiya Group (м. Тебриз, Іран);

X. Піроозініа, MSc, кафедра управління, відділення в м. Бонаб, Ісламський університет Азад (м. Бонаб, Іран)

Визначення факторів впливу на цінність бренда з точки зору потенційних і фактичних споживачів

Метою статті є дослідження та визначення факторів, що впливають на цінність бренда з точки зору потенційних і фактичних споживачів. На основі моделі Аакера і біхевіористичного підходу, а також враховуючи думки потенційних і фактичних споживачів підприємства, було проведено опитування, спрямоване на встановлення взаємозв'язку між різними складовими бренд-моделі Аакера (лояльність до бренда, упізнаваність бренда, якість бренда, асоціації) та цінністю бренда з точки зору споживачів (цінність знань, цінність відношення та цінність взаємозв'язків). Відбір респондентів був проведений на основі кластерної випадкової вибірки, а збір даних було здійснено на основі стандартної анкети для оиінювання цінності бренда Іо і Денту. Отримані результати показують, що лояльність до бренда, упізнаваність бренда та його якість впливають на цінність бренда з точки зору фрактичних споживачів. Також 
отримані результати дозволяють покращити процес пошуку ефективних стратегій, що дасть можливість підвищити иінність бренда. Для практичного використання отриманих результатів показники, що впливають на цінність бренда, рекомендується подати у вигляді стверджень в анкеті, що дозволить виміряти їх значення. Заповнення анкети менеджерами дасть змогу оцінити готовність підприємства до підвищення цінності бренда.

Ключові слова: цінність бренда, лояльність до бренда, обізнаність щодо бренда, сприймана якість бренда, асоціації.

X. Гхарехбигло, ассистент, кафедра управления, отделение в г. Аджаб Шир, Исламский университет Азад (г. Аджаб Шир, Иран);

A. Сеуед Moфud, MSc, кафедра управления, отделение в г. Бонаб, Исламский университет Азад (г. Бонаб, Иран);

E. Сирооснезхад Цхарандаби, аспирант, кафедра управления, отделение в г. Аджаб Шир, Исламский университет Азад (г. Аджаб Шир, Иран), генеральный директор компании "Mobiya Market Research", Mobiya Group (г. Тебриз, Иран);

X. Пироозиниа, MSc, кафедра управления, отделение в г. Бонаб, Исламский университет Азад (г. Бонаб, Иран)

Определение факторов влияния на ценность бренда с точки зрения потенциальных и фактических потребителей

Целью статьи является исследование и определение факторов, влияющих на ценность бренда с точки зрения потенциальных и фактических потребителей. На основе модели Аакера и бихевиористического подхода, а также учитывая мнения потенциальных и фрактических потребителей предприятия, был проведен опрос, направленный на установление взаимосвязи между различными составляющими бренд-модели Аакера (лояльность к бренду, узнаваемость бренда, качество бренда, ассоциации) и ценностью бренда с точки зрения потребителей (ценность знаний, ценность отношений и ценность взаимосвязей). Отбор респондентов был проведен на основе кластерной случайной выборки, а сбор данных был осуществлен на основе стандартной анкеты оценки ценности бренда Ио и Дента. Полученные результаты показывают, что лояльность к бренду, узнаваемость бренда и его качество влияют на ценность бренда с точки зрения фактических потребителей. Также полученные результаты позволяют улучшить процесс поиска эфрфективных стратегий, что даст возможность повысить иенность бренда. Для практического использования полученных результатов показатели, влияющие на ценность бренда, рекомендуется представить 8 виде утверждений в анкете, что позволит измерить их значения. Заполнение анкеты менеджерами позволит оценить готовность предприятия к повышению ценности бренда.

Ключевые слова: ценность бренда, лояльность к бренду, осведомленность о бренде, воспринимаемое качество бренда, ассоциации.

Отримано 25.02.2016 p. 